\title{
Abbreviations
}

$\begin{array}{ll}\text { ACA } & \text { (Office of) Asian Communist Affairs } \\ \text { CCNE } & \text { Chinese Communist Nuclear Explosion } \\ \text { CCP } & \text { Chinese Communist Party } \\ \text { ChiCom } & \text { Chinese Communists } \\ \text { CIA } & \text { Central Intelligence Agency } \\ \text { CINCPAC } & \text { Commander in Chief, Pacific } \\ \text { CRG } & \text { Cultural Revolution Group } \\ \text { CWIHP } & \text { Cold War International History Project (Washington, DC) } \\ \text { DRV } & \text { Democratic Republic of Vietnam (North Vietnam) } \\ \text { DSB } & \text { Department of State Bulletin } \\ \text { EA } & \text { Bureau of East Asian and Pacific Affairs, Department of } \\ & \text { State (from November 1966) } \\ \text { FE } & \text { Bureau of Far Eastern Affairs, Department of State } \\ & \text { (1949-October 1966) } \\ \text { FO } & \text { Foreign Office } \\ \text { FRUS } & \text { Foreign Relations of the United States } \\ \text { GRC } & \text { Government of the Republic of China (Taiwan) } \\ \text { INR } & \text { Bureau of Intelligence and Research, Department of State } \\ \text { ISA } & \text { Bureau of International Security Affairs, Department of } \\ & \text { Defense } \\ \text { JCT Papers } & \text { James C. Thomson Papers (JFKL) } \\ \text { JFK } & \text { John Fitzgerald Kennedy } \\ \text { JFKL } & \text { John Fitzgerald Kennedy Library (Boston, Massachusetts) } \\ \text { LBJ } & \text { Lyndon Baines Johnson } \\ \text { LBJL } & \text { Lyndon Baines Johnson Library (Austin, Texas) } \\ \text { NA } & \text { National Archives (College Park, Maryland) } \\ & \end{array}$


NIE National Intelligence Estimate

NLF National Liberation Front

NSC National Security Council

NSCM National Security Council Meetings

NSF National Security File

$\mathrm{OH} \quad$ Oral History

PKI Indonesian Communist Party

PLA People's Liberation Army (PRC)

PPC Policy Planning Council, Department of State

PPP:LBJ Public Papers of the Presidents: Lyndon B. Johnson

PRC People's Republic of China

PRO Public Record Office (Kew, London)

RG Record Group

SNIE Special National Intelligence Estimate

TIM Thailand Independence Movement

UN United Nations

WPB Papers William P. Bundy Papers (LBJL)

\section{Note on transliteration}

Chinese names and places are rendered throughout the text in the Pinyin system of transliteration, except where they occur in different form in quotations, or where familiar names might be confused if changed. 